\title{
Historia
}

\section{Literatura y medicina en los estudios del profesor Sánchez-Granjel sobre la Generación del 98}

\section{Literature and medecine in the professor Sánchez- Granjel's work on the Generation of ' 98}

\section{Literatura e medicina em estudos do professor Sánchez-Granjel na Geração de noventa e oito}

\author{
Francisco Herrera-Rodríguez ${ }^{1}$ y José María Urkía-Etxabe ${ }^{2}$ \\ ${ }^{1}$ Facultad de Enfermería y Fisioterapia (Universidad de Cádiz) \\ ${ }^{2}$ Facultad de Medicina (Universidad del País Vasco)
}

Cómo citar este artículo en edición digital: Herrera Rodríguez, F. y Urkía-Etxabe, J.Ma. (2014) Literatura y medicina en los estudios del profesor Sánchez-Granjel sobre la Generación del 98. Cultura de los Cuidados (Edición digital) 18, 38. Disponible en: http://dx.doi.org/10.7184/cuid.2014.38.07>

Correspondencia:Francisco Herrera-Rodríguez. Facultad de Enfermería y Fisioterapia. Avda. Ana de Viya, 52. 11009-Cádiz. Correo electrónico: francisco.herrera@uca.es.

Recibido: 10/11/2013; Aceptado: 14/01/2014

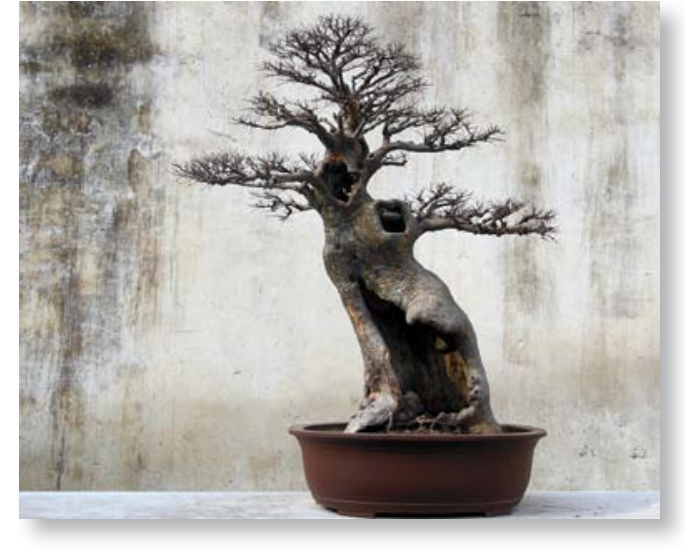

ABSTRACT

Luis Sánchez Granjel is one of the key personalities in the modern Spanish Medical Historiography, not only for his teaching in the University of Salamanca -where he supervised tens of projects and doctoral thesis- but for his investigative labour showed in books, monographs, articles and talks.

In this article we focus on his research into the History of Spanish Literature, concretely on the Generation of '98 mainly through figures such as: Santiago Ramón y Cajal, Felipe Trigo, Pío Baroja and Azorín.

Key words: Literature, History of Literature, History of Medicine, Generation of '98, Modernism, Santiago Ramón y Cajal, Pío Baroja, Felipe Trigo, Azorín.

\section{RESUMO}

Luis Sanchez-Granjel é uma das figuras-chave na moderna historiografia médica espanhola, tanto para o seu ensino dentro da Universida de Salamanca, direcionando dezenas de dissertações e teses, para o próprio trabalho de pesquisa refletida nos livros, monografias, artigos e palestras. Neste artigo vamos nos concentrar na sua pesquisa sobre a história da literatura espanhola, particularmente em estudos que relacionam a medicina ea literatura no contexto da Geração de 98, principalmente por meio de figuras como 
Santiago Ramón y Cajal, Felipe Trigo, Pío Baroja e Azorín.

Palavras-chave: Literatura, História da Literatura, História da Medicina, 98 Geração, Modernismo, Santiago Ramón y Cajal, Pío Baroja, Felipe Trigo, Azorín.

\section{RESUMEN}

Luis Sánchez Granjel es una de las figuras clave de la moderna historiografía médica española, tanto por su magisterio en el seno de la Universidad de Salamanca, dirigiendo decenas de tesinas y de tesis doctorales, como por la labor de investigación propia reflejada en libros, monografías, artículos y conferencias. En el presente artículo nos centramos en su actividad investigadora dentro de la historia de la literatura española, y más concretamente en aquellos estudios que relacionan medicina y literatura en el contexto de la llamada Generación del 98, fundamentalmente a través de figuras como Santiago Ramón y Cajal, Felipe Trigo, Pío Baroja y Azorín.

Palabras clave: Literatura, Historia de la Literatura, Historia de la Medicina, Generación del 98, Modernismo, Santiago Ramón y Cajal, Pío Baroja, Felipe Trigo, Azorín.

\section{Al profesor don Luis Sánchez Granjel por su magisterio historiográfico y literario}

En el mes de septiembre de 2013 se le rindió un homenaje al profesor Sánchez Granjel por su noventa y tres cumpleaños (figura 1), pero el acto no se limitó a la referida celebración sino que a la par se presentó otro libro suyo titulado "La Academia Nacional de Medicina en la Segunda República (La Academia en San Sebastián)". Esta circunstancia creemos que lo expresa todo: una persona nonagenaria que aún tiene capacidad intelectual y entusiasmo para aquilatar y publicar una obra como la que acabamos de citar. Esto, quizás, puede extrañar a los que no lo conozcan, pero no a aquellos que vienen leyéndolo desde hace décadas porque saben de su rigor y de su capacidad de trabajo, todo ello pasado por el cedazo de un hombre tranquilo que tiene una voluntad de hierro.

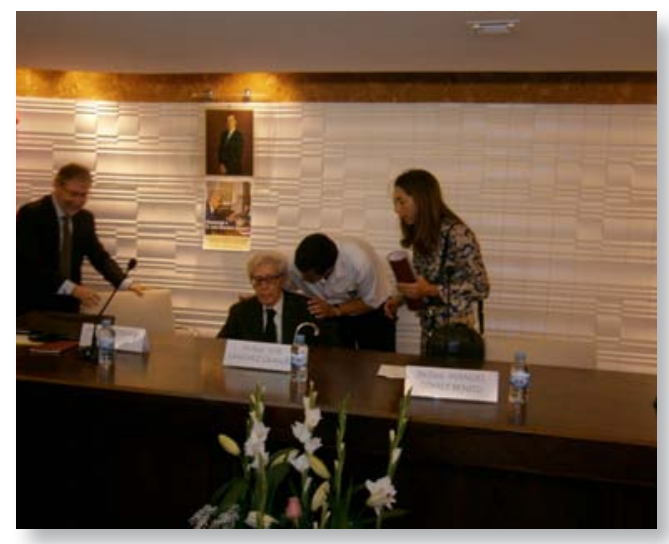

Figura 1: El profesor don Luis Sánchez Granjel en el Colegio de Médicos de Salamanca el día 7 de septiembre de 2013, con motivo del referido homenaje (Fotografía de FHR)

Hace algunas décadas el ya fallecido y recordado periodista Felipe Mellizo hizo un reportaje sobre la labor historiográfica del profesor Luis Sánchez Granjel y denominó de forma genérica a las personas que se dedican a los quehaceres historiográficos como "cazadores de recuerdos"; efectivamente, Mellizo, dio con la imagen literaria precisa para definir también a este eximio historiador de la medicina porque el profesor Granjel es un cazador de recuerdos cuya paciencia le ha permitido poner las bases documentales e interpretativas de la moderna historiografía médica española en decenas de libros y cientos de artículos que son imposibles de nombrar en este estudio que presentamos en las páginas que siguen. 
Este artículo, en cambio, no lo vamos a dedicar a su labor historiográfica en los archivos, sino a ese otro perfil de su obra tan querido por él desde su juventud, nos referimos a sus ensayos literarios y más específicamente a los que dedicó a la Generación de 1898, promoción literaria de la que sin lugar a dudas es uno de los grandes especialistas en nuestro país, debiéndose tener en cuenta que algunos de sus trabajos han resistido el pasado del tiempo porque superan las cinco décadas de existencia. En este trabajo, pues, centraremos nuestra mirada en las cuestiones médicas estudiadas por él al abordar figuras tan señeras de nuestra literatura como Pío Baroja, Felipe Trigo, José Martínez Ruiz, Azorín, sin olvidarnos de una figura médica de la talla de Santiago Ramón y Cajal sobre el cual el profesor Granjel se planteó en su momento si había que incluirlo o no como miembro de la citada Generación.

Este perfil de estudioso de la literatura no puede extrañar de ninguna manera en un historiador como el profesor Granjel porque él también ha cazado los recuerdos en este ámbito, para comprobarlo conviene repasar su "Historia General de la Medicina Española", en cinco volúmenes, en la cual abundan las referencias literarias de autores como Lope de Vega, Quevedo, Calderón, Tirso, Moratín o Benito Pérez Galdós, por citar sólo algunos ejemplos. No podemos olvidar que nuestro autor ha sido pionero en España en la utilización rigurosa de la literatura como fuente de conocimiento de la labor de los médicos, cirujanos, barberos sangradores, etc. El profesor Granjel a este perfil de sus investigaciones lo denominó "Medicina en la Literatura", aspecto que él mismo ha expresado muy certeramente en su obra "Memoria personal":

“...un aprendizaje como historiador realizado indagando extramuros del cercado de lo que oficialmente se consideraría auténtico pasado médico; los más benévolos en el juicio seguramente entonces no pasarían de calificar aquellos campos recorridos en mis exploraciones como 'arrabales' de la Medicina. Hoy me atribuyo autoridad suficiente para sostener, sin temor a ser desmentido, que aquellos 'arrabales' forman parte, y no desdeñable, de un pasado que es obligado conocer para recomponer en su auténtica realidad lo que la Medicina, y con ella la enfermedad en su presencia social, fue en las distintas etapas de la vida colectiva española”.

Para un mejor entendimiento vertebraremos nuestro trabajo en tres apartados: en el primero realizaremos una síntesis de su biografía, luego trazaremos un panorama general sobre la citada Generación de 1898, o como al profesor Granjel le gusta denominarla "Promoción literaria de la Regencia”, y finalmente abordaremos los aspectos médicos y literarios en la vida o en la obra de los autores citados anteriormente.

\section{SÍNTESIS DE LA BIOGRAFÍA ACADÉ- MICA.}

Luis Sánchez Granjel nace el 26 de agosto de 1920 en Guipúzcoa, concretamente en la villa de Segura, fruto del matrimonio formado por Gerardo Sánchez, médico rural, y Carmen Granjel. Como bien ha apuntado Luis Carlos Tejerizo, en su extensa y amena biografía, el pequeño Luis pasó en esta población doce años de su vida desde 1920 hasta 1932. Comenzó a estudiar el bachillerato en Santiago de Compostela y lo terminó en 1936 en el Instituto de Béjar, año en que comenzó nuestra trágica guerra civil. Durante los tres años que dura la contienda lee compulsivamente el periódico "Ahora", dirigido por Manuel Chaves Nogales, periodista que en los últimos años está siendo muy justamente rehabilitado con biografías, 
reediciones o con la consideración de un precursor de lo que se ha dado en llamar "Nuevo Periodismo". En las páginas de la mencionada publicación escribían autores que marcaron el interés de Granjel en las siguientes décadas, nos referimos a Baroja, Unamuno, Azorín, etc.

La carrera de medicina la cursó en Salamanca entre 1939 y 1945, pero muy pronto comprobó que su vocación de galeno flaqueaba mientras que la literatura se iba imponiendo en sus afanes intelectuales. A pesar de ello se especializó en Psiquiatría e instaló una consulta de esta especialidad en Salamanca, tampoco podemos olvidar que en 1948 defendió su tesis doctoral titulada "La psicología de Carl Gustav Jung en las relaciones entre medicina y religión". En la década de los cuarenta sucede algo importante en su biografía académica; en el curso 1945-46 comenzó su carrera docente, como profesor Ayudante de Farmacología y Anatomía, y a partir de 1948 empezó a explicar la Historia de la Medicina primero como encargado de curso y luego como encargado de cátedra, hasta que en 1955 obtiene por oposición la cátedra que desempeñará hasta su jubilación en 1986. El profesor Granjel expone en "Una vida de historiador" sus comienzos al frente de la citada disciplina, leamos algunos párrafos porque en ellos vuelve a hacer hincapié en su interés por los estudios literarios:

"Al iniciarse el año académico 1948-1949 se hizo efectiva la enseñanza de la Historia de la Medicina en el período de licenciatura, conocimiento que hasta la fecha sólo era exigido a quienes realizaban, en la Universidad Central, los estudios de doctorado (...). En el Claustro de la Facultad nadie se consideró con preparación para hacerse cargo de la nueva disciplina, a la que pienso no se otorgaba valor formativo; aquel desinterés debió influir en la decisión de quien entonces ostentaba el gobierno de la Fa- cultad de encomendarme una misión académica para la que no encontraba postulante; acaso propició esta elección el que ya entonces se me atribuyeran veleidades de aprendiz de escritor $y$ siempre sobre cuestiones poco o nada relacionadas con la profesión que ejercía”.

Precisamente esas veleidades de aprendiz de escritor son las que Granjel ha calificado refiriéndose a sí mismo como "la tentación literaria" y su interés por la "reflexión crítica", ya en 1949 publicó un breve artículo sobre la enfermedad en "La Montaña mágica" de Thomas Mann, y a lo largo de la década de los cincuenta se dedicó con especial atención a esta tarea que ha sido una constante a lo largo de su trayectoria académica, hecho que podemos comprobar en trabajos más cercanos en el tiempo como "Literatura y medicina en la época del Noventa Ocho" (1998), "Lectura médica de <El Quijote>" (2005), "Literatura y medicina" (2001) o un capítulo con el mismo título que se puede leer en la obra "Medicina y humanidades" (2011), coordinada por el profesor Gracia Guillén. Entraremos en más detalles de sus publicaciones literarias, y más concretamente sobre la Generación de 1898 en los siguientes apartados de nuestro trabajo, ahora conviene apuntar que en la citada década de los cincuenta ya publicó estudios sobre los médicos y los boticarios en la literatura picaresca o sobre la medicina en "La Lozana andaluza". No Podemos olvidar su discurso de ingreso en la Real Academia de Medicina de Salamanca, en 1973, titulado "Médicos novelistas y novelistas médicos" en el cual estudia a los novelistas médicos en relación con la literatura picaresca y la novela histórica o al propio Pío Baroja. Otro aspecto que debe tenerse muy en cuenta es su magisterio en esta particular línea de trabajo, dirigiendo tesinas y tesis doctorales entre las que podemos destacar, sin ánimo de 
agotar la nómina, las dedicadas a estudiar la obra de Calderón de la Barca, Benavente, Mesonero Romanos o la que le dirigió al que años más tarde sería su biógrafo, Luis Carlos Tejerizo López, sobre la enfermedad en la novela española de posguerra; noticia detallada de estos trabajos de grado puede encontrarse en la ya citada obra "Memoria personal".

No hay que olvidarse de que en su larga trayectoria académica el profesor Granjel ha explicado también disciplinas como la Historia de la Psicología en el seno de la Universidad Pontificia de Salamanca, y la Historia de la Gerontología en el contexto de diversos másteres, esta es una cuestión que no podemos abordar en este artículo porque debemos emprender ya la tarea que nos hemos propuesto que no es otra que la de realizar un acercamiento a las cuestiones médicas en la Generación del Noventa y Ocho, aunque a los más interesados en profundizar en su trayectoria académica, además de la citada biografía de Tejerizo o los propios libros que a esta tarea ha dedicado el profesor Granjel, recomendamos el estudio del profesor Riera Palmero titulado "Medio siglo de historiografía médica española: aproximación a la obra de Luis S. Granjel”, en el cual deja bien claro que "en el quehacer intelectual de Luis S. Granjel se confunde la vocación de historiador médico y de historiador de la literatura española".

\section{PANORAMA LITERARIO DE LA GENE- RACIÓN DEL NOVENTA Y OCHO}

El profesor Sánchez Granjel ha publicado estudios sobre el particular en revistas médicas e historicomédicas, pero a la vez ha tenido la visión de reunir muchos de estos trabajos en libros, haciendo referencia expresa en los mismos cuando reproduce esos artículos en qué revistas fueron publicados, hecho que fa- cilita la tarea de las personas interesadas en su lectura. Conviene, pues, que en primer lugar hagamos referencia expresa a estos textos que configuran la obra publicada por Granjel sobre esta Generación o monográficamente sobre algunos de los que son considerados sus miembros. En primer lugar debemos destacar la serie de publicaciones que salen a la luz pública bajo el denominador común de "retratos": "Retrato de Pío Baroja" (1953), "Retrato de Unamuno" (1957) y "Retrato de Azorín" (1958). A este ciclo seguirían libros como "Panorama de la Generación del 98" (1959) (figura 2), "Baroja y otras figuras del 98" (1960), "La Generación literaria del 98" (1966), "Maestros y amigos de la Generación del Noventa y Ocho" (1981), "El último Baroja" (1992) y "Psicobiografía de Unamuno (un ensayo de interpretación)" (1999). En esta nómina no puede faltar la selección y estudio preliminar realizado de la obra de Silverio Lanza (1966). Como obra de conjunto el propio Granjel en su libro "Memoria personal" reconoce que su ensayo "Panorama de la Generación del 98” es el más ambicioso de sus proyectos literarios sobre estos autores, "obra que privada de su aparato documental, y con título algo reformado < La Generación literaria del 98>, tuvo tres reimpresiones".

No vamos a descubrir aquí la abundantísima bibliografía existente sobre esta Generación y las controversias que esta etiqueta literaria ha generado y sigue generando, avisamos que no es nuestro propósito exponer en este artículo una pormenorizada historiografía sobre esta cuestión, sino fijar las principales ideas del profesor Granjel sobre esta Generación, de manera que sirva de marco al estudio de algunas cuestiones médicos literarias que plantearemos en próximos apartados. 
LUIS S. GRANJEL

\section{PA NOR A M A \\ D E L A \\ GENERACION DEL 98}

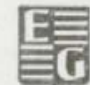

EDICIONES GUADARRAMA, S. L.

Calle del Prado, 24

M A D RID

Figura 2: Portada de "Panorama de la Generación del 98” de Luis S. Granjel.

En lo que se refiere a los llamados por Granjel "retratos" ha precisado el profesor Diego Gracia lo siguiente:

"Ha escrito libros sobre Unamuno, sobre Azorín, sobre Baroja, sobre Ramón Gómez de la Serna, sobre Marañón. No son, en el rigor de los términos, <biografías>, sino otra cosa que él denominó, creo que con toda justeza $<$ retratos $>$ (...). No quiere <interpretar $>$ a los personajes, $n i<$ comprenderlos $>$, en el sentido diltheyano de ese término. Su objetivo es el de <retratarlos $>$ al modo del pintor que dibuja con trazos escuetos y rápidos las facciones de una persona. No le hacen falta más. Cuatro líneas bien dibujadas son capaces de transportarnos a un inmenso mundo interior, repleto de sentido. Es la estética de la sugerencia y de la sobriedad".
Estamos de acuerdo con esta idea de la estética de la sobriedad, ya que la claridad y la concisión presiden toda su obra, pero a esto hay que añadir el enorme esfuerzo de Granjel en lo que se refiere a la crítica y a la erudición literarias, en cualquiera de los libros que hemos apuntado se puede comprobar este hecho; una erudición firme que también aplica a sus reflexiones sobre los "noventayochistas".

El profesor Granjel señala a Azorín, y más concretamente a escritos de este autor fechados entre 1905 y 1915, como la figura clave que intenta dibujar el perfil colectivo de su generación, señalando como elementos comunes en ellos el ansia de renovar y de ensanchar el idioma, uniendo a este propósito el deseo de estudiar la verdadera vida española y el paisaje de España. Azorín, según Granjel, es el primero en usar el término Generación del 98 incluyéndose en la misma junto a Miguel de Unamuno, Pío Baroja, Ramiro Maeztu, Rubén Darío, Ramón María del Valle-Inclán y Jacinto Benavente. Granjel hace una matización importante y es que Azorín considera autores de esta Generación a "los que en rigor merecen ser nombrados 'noventayochistas' y con ellos quienes encabezan, en España, la renovación modernista"; es decir, Rubén Darío, Benavente y Valle-Inclán. Sucede que a Maeztu, Unamuno y Baroja no les gustó mucho esta etiqueta o rótulo, aunque Baroja acaba aceptando la existencia de una "generación de 1870"; considerando Baroja que los componentes de la misma eran profundamente individualistas, pero con gran preocupación ética y anhelantes de una mayor justicia social. Granjel piensa que "también hicieron número" en esta Generación escritores como Blasco Ibáñez, Felipe Trigo o Eduardo Zamacois.

Al estudiar Granjel la bibliografía sobre esta Generación literaria señala en "Maes- 
tros y amigos de la Generación del Noventa y Ocho", la aportada por José María Salaverría, Melchor Fernández Almagro, Pedro Salinas y Guillermo Díaz-Plaja, haciendo hincapié sobre todo en estos dos últimos. Salinas incluye en esta Generación a Unamuno, Baroja, Azorín, Maeztu, Valle-Inclán, Benavente y los hermanos Manuel y Antonio Machado, mientras que Díaz Plaja considera como miembros de la misma a los 'noventayochistas', independizando al grupo de escritores modernistas que agrupa como Generación de 1902, aunque este autor perfila aún más este asunto, por eso Granjel apunta lo siguiente: "En uno y otro grupo deslinda, a su vez, dos promociones, ateniéndose a un criterio cronológico. La primera promoción de la Generación del Noventa y Ocho la compondrían Unamuno y Ganivet y en la Generación de 1902 o 'modernista' Benavente, Valle Inclán y Rubén Darío; la segunda promoción estaría integrada por Baroja, Azorín, Maeztu y Antonio Machado en el grupo 'noventayochista y por Villaespesa, Manuel Machado, Marquina, Juan Ramón Jiménez y Gregorio Martínez Sierra en el grupo modernista”. Sin embargo, Granjel, considera que la aportación más valiosa sobre el asunto que venimos tratando es la de Pedro Laín Entralgo que compone su nómina con los nombres de Unamuno, Azorín, Antonio Machado, Pío Baroja, Valle-Inclán y Menéndez Pidal, aunque sitúa a su lado, "precediéndoles o subsiguiéndoles", a Ganivet y Ramiro de Maeztu, a Benavente, Manuel Machado, los hermanos Álvarez Quintero, a Manuel Bueno, a Silverio Lanza y al pintor Darío de Regoyos.

Se han manejado para todas estas clasificaciones sobre la Generación, entre otros, el gusto por determinados autores, los criterios estéticos, el amor por el paisaje castellano y las fechas de nacimientos de los autores citados, que por conocidas no las vamos a repetir aquí. Después de esta apretada síntesis de tan controvertido problema histórico literario, cabe decir que Sánchez Granjel cree más conveniente utilizar para la llamada Generación del 98 el calificativo de "Promoción literaria de la Regencia", ante esta propuesta granjeliana lo mejor es rescatar sus propias palabras porque demuestran que no pasó de puntillas sobre el asunto sino que trató de aportar matices y propuestas concretas, en este caso en la obra ya citada y publicada por él en 1981. Leamos:

"Nada han escrito sobre la Generación, en la que no obstante hicieron número, Benavente o Valle-Inclán, Blasco Ibáñez, Felipe Trigo o Eduardo Zamacois, y ello, no cabe dudarlo, porque en la titulada por Azorín Generación de 1898, que yo creo más justo rotular Promoción literaria de la Regencia, la conciencia generacional únicamente afloró en quienes, entre sus componentes, se interesaron por la circunstancia, histórica y social, que ponía marco a sus vidas e incluso buscaron ajustar aquella realidad, fracasando desde luego en el empeño, a la horma de sus personales ilusiones, a la imagen de una España en la que siempre les fue grato soñar".

Además, Sánchez Granjel, en su "Panorama de la Generación del 98", publicado en 1959, y más concretamente en la nota preliminar a esta obra ya demostró su incomodidad con la citada denominación:

"Empezaré advirtiendo cómo si bien en el rótulo que la encabeza se habla de "Generación del Noventa y Ocho", su contenido trata de demostrar, y creo lo consigue, que de aceptarse la existencia de tal generación, a juicio mío discutible, resulta inadecuado conferirle, para nombrarla, la fecha del desastre colonial, suceso éste 
que únicamente influyó, a ellos sí de modo decisivo, en una fracción de los escritores en aquélla encuadrados, a quienes ayudó a agruparse, y a los que aquí se confiere, por ello, el calificativo de 'noventayochistas'. Integran el grupo Miguel de Unamuno, Pío Baroja, Azorín y Ramiro de Maeztu".

En esta obra Granjel revisa las doctrinas de regeneración, política y social, de la vida española, sostenidas "individualmente" por los citados autores, que "se inspiran en el particular clima de revisionismo suscitado en España por el triste final al que desemboca, iniciado el verano de 1898, la guerra colonial tras haber enfrentado pocos meses antes a la nación con el poderío militar yankee". Volveremos sobre este asunto cuando abordemos la figura de Santiago Ramón y Cajal en el contexto de la España finisecular, ahora sólo cabe apuntar que desde Ortega y Maeztu se ha discutido sobre el valor de la "Generación" frente al problema de España y la política española, pero que este asunto ha seguido interesando a autores como Blanco Aguinaga, Vicente Cacho Viu, Miguel Cruz Hernández o a hispanistas como E. Innman Fox y Herbert Ramdsen, por citar sólo a algunos autores ya que sería inacabable la nómina. Un autor como Antonio Heredia-Soriano ha descrito el concepto de "Generación del 98" como una "moneda gastada" y José-Carlos Mainer ha señalado que Unamuno, Valle-Inclán, Baroja, Azorín y Antonio Machado, constituyen un elenco de escritores que es muy discutible que compongan una generación (entre los nacimientos de Unamuno y Machado median once años de diferencia), "pero de quienes puede decirse que encarnaron la construcción de la modernidad literaria en España. Quizá en tal sentido podría acogerlos el rótulo de modernistas tanto en el sentido hispánico como en la acepción anglosajona del término: por su vivencia personal de la búsqueda de un lenguaje expresivo, por su conciencia clara de los géneros literarios tradicionales, por su peculiar modulación del yo artístico, tres ingredientes capitales del arte de nuestro tiempo". Como podemos observar el tema que abordamos aquí es inagotable y sigue vivo; el caso es que, Granjel, con todos los matices que se quieran apuntar ya se mostraba crítico con este concepto hasta el extremo de afirmar que consideraba muy discutible la existencia de tal Generación como acabamos de ver, prefiriendo el rótulo o etiqueta de "Promoción literaria de la Regencia". De hecho en el año 2003, en una entrevista que le realizó el profesor Carreras Panchón, al ser interpelado sobre el término "generaciones" el profesor Granjel clarifica perfectamente su pensamiento sobre este término y más concretamente sobre la Generación del 98. Leamos su respuesta:

"Yo suelo decir que, en cierta medida, soy culpable de que se generalizase el término "generación" pero, ahora, prefiero hablar de cotidianidad, a pesar de que este tipo de términos son útiles porque te permiten calificar la época. En concreto, en el caso de la Generación del 98, hay autores que no creen en ella, por ejemplo, Baroja. El concepto persiste porque eso permite agrupar a una serie de escritores que tenían tendencias totalmente distintas. Personalmente creo que el término "generación" ya no se puede utilizar. Ahora yo hablaría de promociones que estaban conviviendo, coexistiendo y que se influyen mutuamente".

\section{LITERATURA Y MEDICINA EN 'LAS PROMOCIONES LITERARIAS DE LA RE- GENCIA'}

Este apartado de nuestro estudio, debido a los límites que marcan un artículo, se va a 
centrar en tres figuras médicas estudiadas por Granjel, nos referimos a Cajal, Felipe Trigo y Pío Baroja, y por último abordaremos la figura de Azorín a través de la visión que da este autor en su obra de los médicos y de los enfermos. Antes de desarrollar el programa apuntado nos gustaría destacar un aspecto más con el que se refuerza la firme convicción granjeliana de entender la literatura como fuente de conocimiento para la medicina. En la ya citada entrevista a Carreras Panchón señaló que normalmente la Historia de la Medicina se ha estudiado desde la perspectiva del médico, "...pero hay que verla también desde la vivencia del enfermo. El análisis de la literatura confidencial y de la literatura autobiográfica ofrece datos sorprendentes. Creo que las grandes lagunas que hay en la historia de la medicina son, precisamente, la dimensión social y la vivencia de la enfermedad desde el factor humano". Una vez más la literatura y en este caso como fuente de conocimiento de la vivencia de la enfermedad, en esta línea no cabe duda de que el profesor Granjel es pionero también sobre todo cuando ha estudiado estos aspectos, por ejemplo, en la obra de Unamuno o de Azorín. No incluiremos en este artículo comentarios sobre la psicobiografía que Granjel realizó de Miguel de Unamuno porque ha sido glosada recientemente en "Las enfermedades de Sísifo", aunque no descartamos volver sobre la misma en futuros trabajos; sí dedicamos en cambio algunas páginas a la obra azoriniana en torno a la medicina y la enfermedad.

En el desarrollo del programa que hemos planteado nos ayudarán diversas obras del profesor Granjel, pero muy particularmente su libro "Baroja y otras figuras del 98" (1960) (figura 3).

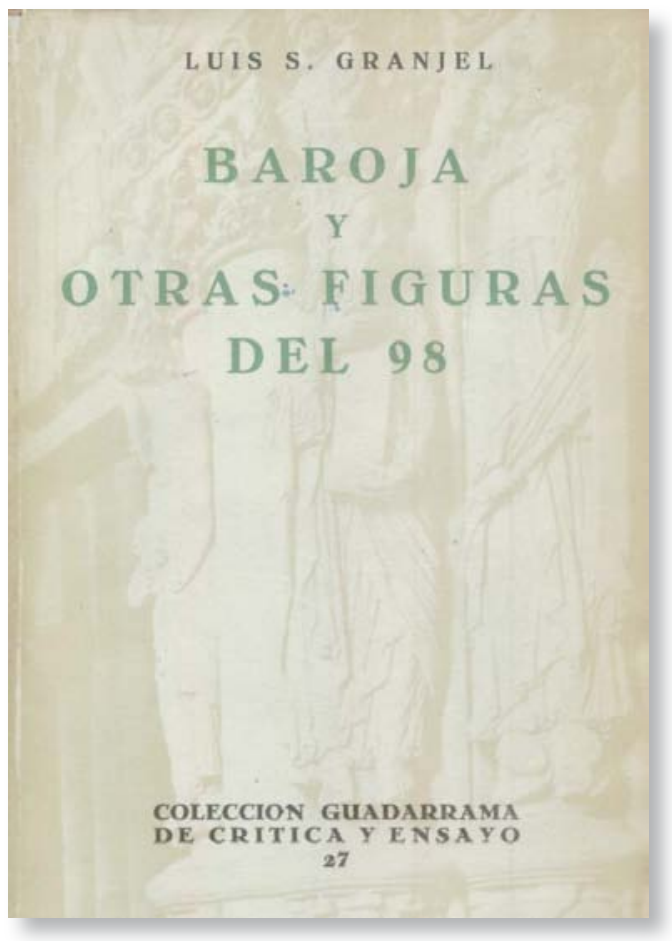

Figura 3: Portada de "Baroja y otras figuras del 98" de L. Sánchez Granjel.

\subsection{CAJAL, ¿UN HOMBRE DEL 98?}

$\mathrm{Al}$ ser una figura tan conocida y reconocida que cuenta con varias biografías no vamos a insistir aquí con una síntesis de su vida y obra, nuestro cometido principal es indagar sobre un aspecto concreto desarrollado por Granjel. Santiago Ramón y Cajal nació como es sabido en 1852. Si partimos de esta fecha parece muy complicado ubicar a Cajal dentro de la llamada, para bien o para mal, Generación del 98, sobre todo si se tiene en cuenta que Miguel de Unamuno nació en 1864 y Pío Baroja en 1872, precisamente Cajal fue miembro del tribunal que juzgó la tesis doctoral sobre el dolor del novelista vasco; pero claro está que no es este el problema que se planteó Granjel sino otro muy diferente, el de buscar rasgos comunes que identifique la actitud de Cajal con la de los hombres del 98, cosa muy distinta. 
Cabe recordar, por ejemplo, que en 1905 se conmemoró el tricentenario de la publicación de la primera parte de El Quijote, y aquí encontramos, según apunta Granjel, un denominador común con Unamuno y Azorín. Cajal ofreció una conferencia en el Colegio de Médicos de San Carlos, de Madrid, la noche del 9 de mayo de 1905 titulada "Psicología de Don Quijote y el quijotismo". En el mismo año Unamuno publicó "Vida de Don Quijote y Sancho" y Azorín publicó una serie de crónicas periodísticas en el diario "El Imparcial" que están recogidas en el libro "La ruta de don Quijote". Granjel lo tiene muy claro:

"Para los 'noventayochistas' Unamuno y Azorín, también para Cajal, aquella exaltación del hidalgo tuvo un significado mucho más profundo que el de una obligada rememoración de centenario; su actitud no era la de eruditos que olvidados del presente se adentra con fruición en un pasado más o menos remoto. Ven en Don Quijote un símbolo cuya actualidad no se circunscribe a la situación, ya lejana, en que tal encarnación literaria fue creada por Cervantes, pues, nos dirán, dentro del vivir hispánico, intemporal; actual, por tanto, en aquel presente, tan acosado por irresueltos e inquietantes problemas, de los primeros años de nuestra centuria, (...). El mito de Don Quijote es una de las más significadas creaciones de los nombres del Noventa y Ocho".

Acertadamente apunta Granjel que el donquijotismo en Cajal es patriotismo, de hecho Unamuno llegó a decir de él que "Cajal es uno de nuestros más grandes y más sanos patriotas", y es que el histólogo aragonés se resistía a que en España los dominios del arte, de la filosofía y de la ciencia estuvieran "huérfanos de alentadores y excelsos quijotismos".

Dentro del citado libro "Baroja y otras figuras del 98”, Granjel incluye un capítulo titulado
"Cajal y la Generación del Noventa y Ocho" a partir del cual vamos a fundamentar nuestros comentarios. En este escrito insiste Granjel en el parecido en ciertos aspectos de la personalidad de Cajal " $y$ la de los literatos que hoy conocemos con el nombre de noventayochistas", documentando críticamente su afirmación con autores como Gregorio Marañón o Guillermo Díaz Plaja, este último autor lo consideraba incluso el más puro representante de la Generación del 98; pero como podemos apreciar nuevamente Granjel demuestra en el siguiente párrafo un gran vigor analítico al no hacer seguidismo de lo que afirman los grandes estudiosos, manteniendo un criterio propio:

"El juicio del doctor Marañón encierra una leve inexactitud que conviene rectificar; cronológicamente Ramón y Cajal no puede ser incluido en el grupo que forman los hombres del Noventa y Ocho, pues le separan doce años de Unamuno, el más viejo de la generación, y tenía cerca de veinte en 1870, la fecha en torno a la cual se agrupan las que señalan el nacimiento de sus más destacados componentes. No obstante, es cierto que entre Cajal y los literatos de tal generación existe un indudable parecido, el cual, aunque no autorice, yo así lo creo, a incluir su nombre entre los de tal grupo generacional, sí nos obliga a escudriñar con la atención que merece en esta semejanza a indagar sobre su razón histórica".

Queda clara, pues, la posición de Granjel en este punto, precisando el citado parecido en la actitud que toma el propio Cajal, común con la de los 'noventayochistas', con motivo del desastre colonial y los problemas de la España finisecular, sobre todo en torno a la idea de "regeneración”. En el análisis de este asunto Granjel se va a apoyar sobre todo en Laín Entralgo que deslindó "tres grupos" de españoles en torno al debate de los problemas de la España 
de la época: los "arbitristas" de la regeneración (Costa, Macías Picavea, etc.), los profesores y hombres de Ciencia (Cajal, Ferrán, Menéndez Pelayo, etc.) y los 'noventayochistas' (Unamuno, Baroja, Azorín, Maeztu). Los tres grupos convergen apasionadamente en la idea "de la regeneración nacional". Cajal expresó su opinión al respecto en un artículo publicado en octubre de 1898 en el diario "El liberal", en el cual reclamaba que había que crear "ciencia original" en todos los órdenes del pensamiento, pues esto tendrá posteriormente aplicación industrial; igualmente hacían hincapié en esta idea en su Manifiesto de 1901 Azorín, Baroja y Maeztu. Otro denominador común entre Cajal y autores como Unamuno o Azorín es la de la voluntad ante el desánimo generalizado, en esta línea muy acertadamente trae a colación Granjel el célebre discurso de Cajal, de finales de 1898, "Reglas y consejos sobre investigación científica”, también conocido como "Los tónicos de la voluntad". De este discurso podríamos extraer varios ejemplos, pero seleccionamos uno que creemos muy significativo al respecto, el que se refiere a la falsa creencia del agotamiento de los temas científicos:

"He aquí uno de los falsos conceptos que se oyen a menudo a nuestros flamantes licenciados: 'Todo lo sustancial de cada tema científico está apurado; ¿qué importa que yo pueda añadir algún pormenor, espigar en un campo donde más diligentes observadores recogieron copiosas mies? Por mi labor, ni la Ciencia cambiará de aspecto, ni mi nombre saldrá de la oscuridad'.

Así habla muchas veces la pereza, disfrazada de modestia. Así discurren algunos jóvenes de mérito al sentir los primeros desmayos producidos por la consideración de la magna empresa. No hay más remedio que extirpar radicalmente un concepto tan superficial de la
Ciencia si no quiere el joven investigador caer definitivamente vencido en esa lucha que en su voluntad se entabla entre las utilitarias sugestiones del ambiente moral, encaminadas a convertirlo en un vulgar y adinerado practicón, y los nobles impulsos del deber y del patriotismo que le arrastran al honor y a la gloria".

Este texto se puede resumir en el célebre aserto que Cajal recoge en este libro: no hay cuestiones agotadas sino hombres agotados en las cuestiones. En esta línea es muy significativo el capítulo titulado "Enfermedades de la voluntad". Y contra esta idea se rebela el histólogo aragonés, doliéndole muy particularmente que entre "las lenguas sabias" no figure el español. Otro denominador común entre Cajal y los 'noventayochistas' es que estos últimos rechazaron el estilo retórico al escribir, y Cajal abogó, también en el citado discurso, por una prosa científica clara y concisa:

"Finalmente, el estilo de nuestro trabajo será genuinamente didáctico, sobrio, sencillo, sin afectación, y sin acusar otras preocupaciones que el orden y la claridad. El énfasis, la declamación y la hipérbole no deben figurar jamás en los escritos meramente científicos si no queremos perder la confianza de los sabios (...). El escritor científico aspirará constantemente a reflejar la realidad objetiva con la perfecta serenidad e ingenuidad de un espejo dibujando con la palabra, como el pintor con el pincel, y abandonando, en fin la pretensión de estilista exquisito y el fatuo alarde de profundidad filosófica".

Granjel señala tres asuntos más en los que atisba parecido entre Cajal y los citados escritores, los apuntamos a continuación para cerrar con ellos estas líneas dedicadas a su figura: primero, el prejuicio ante la política internacional e interna de los monarcas austríacos, aunque en esta línea argumental nuestro histólogo ha recibido críticas historiográficas; 
segundo, sobre el que no vamos a insistir por conocido y tratado, el amor por las tierras de España y el paisaje castellano, y por último, el tema de la mujer y el amor, al cual como es sabido Cajal dedicó algunas páginas. También cabe apuntar, como bien ha visto Granjel apoyándose en Laín Entralgo, que el regeneracionismo militante, tanto en Cajal como en los 'noventayochistas' es fugaz, pronto se desengañan del mismo centrándose en el trabajo como "manera de servir al engrandecimiento de la patria"; aunque es preciso recordar que Unamuno fue una voz muy crítica durante los años de la dictadura de Primo de Rivera y la Segunda República, pero esta es una cuestión que se escapa de los límites de nuestro trabajo.

\subsection{UN NOVELISTA MÉDICO: FELIPE TRIGO}

Felipe Trigo nació en Villanueva de la Serena (Badajoz) en el año 1864, en el mismo año pues que Unamuno, y falleció trágicamente en 1916 cuando Europa estaba escarnecida por la Primera Guerra Mundial, viviéndola el escritor como una "crisis de la civilización". No es lugar este para trazar su biografía, tan sólo indicaremos que estudió la carrera de medicina en Madrid y que ejerció como médico rural en pueblos extremeños; posteriormente ingresó en el Cuerpo de Sanidad Militar con destino primero en Sevilla y posteriormente en Filipinas donde fue herido de gravedad y repatriado; abandonó el ejercicio de la medicina para dedicarse a la literatura con un notable éxito público, quizás por el perfil erótico de algunas de sus narraciones, pero este es un aspecto que abordamos más adelante, al igual que el contenido social de su obra. Su producción novelística puede ser consultada en la bibliografía que acompaña a nuestro trabajo, por eso y sólo a manera de presentación general citaremos "Las ingenuas" (1901), "La sed de amar" (1903), "Alma en los labios" (1905), "En la carrera" (1909), "El médico rural" (1912) (figura 4) y "Jarrapellejos" (1914). Se ha señalado, con razón, que la mayor parte de sus novelas son poco leídas en la actualidad, teniendo mayor vigencia las dos últimas que hemos señalado en nuestra resumida nómina, pero debemos recordar que José Bergamín ha subrayado que Felipe Trigo "nos ha dejado un legado novelístico excepcional, cuya importancia crece a nuestros ojos ahora al revivirlo, al releerle, $y$ que tendrá que ser revalorado de nuevo, pues su riqueza de creación novelesca por el lenguaje imaginativo que la expresa, le coloca, Galdós aparte, a la cabeza de los novelistas españoles de su tiempo". Sabemos que algunos de sus coetáneos no compartían esa idea, Clarín lo acusa de ser un "corruptor de menores y un corruptor del idioma español". Martínez San Martín, en 1983, afirmó que "el desprecio y el olvido han sido hasta hace muy poco, los dos más fieles compañeros de su obra literaria”. Esto es así, pero una vez más encontramos que Granjel lo tuvo en su punto de mira desde la década de los cincuenta, y que en 1975 señaló que "los historiadores de la literatura española de los últimos años, incomprensiblemente, ignoran el nombre y la obra de Felipe Trigo o limitan su referencia a una escueta mención en ocasiones hasta errónea en los datos".

Conviene, pues, citar los principales trabajos de Granjel en torno a la figura del médico y literato extremeño. Dedica algunos comentarios a Felipe Trigo en su "Panorama de la Generación del 98” (1959), así como en "La Generación literaria del 98" (1966), pero donde verdaderamente estudia en profundidad su figura es en la II Reunión Nacional de Médicos Escritores, que tuvo lugar en Mérida 
en el mes de mayo de 1975, en un ensayo titulado "Felipe Trigo. Medicina y Literatura"; posteriormente, en la revista "El Médico", en un número conmemorativo sobre la medicina en el 98 coordinado por Riera Palmero, publicó un breve pero interesante trabajo, en el que se ocupa también de su figura, titulado "Literatura y medicina en la época del Noventa y Ocho", y más recientemente en 2011 ha publicado un capítulo titulado "Literatura y medicina" en el que también hace algunos comentarios. Queda demostrado, pues, el interés de Granjel por la figura de Felipe Trigo con la nómina de trabajos citados, pero aún debemos añadir algo más. Hemos apuntado que el escritor extremeño nace en el mismo año que Unamuno, 1864, quizás esto nos podría conducir a la afirmación de que Trigo fue otro integrante más de la citada Generación del 98 y observamos que Granjel lo considera así, con todas las reservas que tiene para este término y que hemos comentado ya, pero más que por la fecha de nacimiento por otros motivos, al leer el siguiente párrafo no se debe olvidar que Granjel publicó en 1962 un exhaustivo estudio de la "Revista Nueva":

"La inclusión de este escritor en la "Generación del Noventa y Ocho", no admitida de modo generalizado, creo que la justifica la presencia de su firma en publicaciones creadas por la Generación como Germinal (1897) y Revista Nueva (1899).

Víctor Bergasa ha señalado a Felipe Trigo como un modernista europeo y ya hemos apuntado que José-Carlos Mainer afirma de autores como Unamuno, Valle, Baroja, Azorín y Antonio Machado que se puede decir que encarnaron la modernidad literaria en España y que en tal sentido podría acogerlo el rótulo de modernista; asimismo hemos señalado que a algunos de estos escritores les interesó la regeneración social de España y el tema de la mujer. Bergasa afirma que Felipe Trigo fue un novelista sociólogo, buena muestra de ello son sus novelas "El médico rural" y "Jarrapellejos", muy preocupado por la situación de la mujer y por el atraso de la sociedad española, apuntando entre sus ideas la consecución de un hombre y una sociedad nuevas. En cuanto a las influencias europeas no se olvide que Trigo hablaba el francés y admiraba la obra de Zola, Flaubert, Anatole France, etc. La admiración por Zola la compartía Trigo con Blasco Ibáñez, que llegó a visitar al escritor francés en París, y quizás la novela "Madame Bovary" de Flaubert caló también en el espíritu del escritor extremeño más de lo que se ha señalado por la crítica. En la exégesis realizada por Granjel asoman los grandes asuntos que preocuparon a Felipe Trigo: las relaciones hombre-mujer, el problema sexual y la situación social en España. Granjel, apoyándose en Torrente Ballester, considera al escritor extremeño como un médico que está en desacuerdo con su tiempo. Recibió críticas sobre su estilo literario de Clarín y Baroja, entre otros, aunque él consideraba que en el lenguaje literario debe estar subordinada la palabra a la idea. En esta línea observamos que Granjel señala que Trigo aceptó y copió fórmulas del modernismo " $y$ las usa sin fortuna, lo que ha favorecido el rápido envejecimiento de sus obras"; pero también, refiriéndose a lo social, apunta que el escritor extremeño describió, por ejemplo, en "Jarrapellejos" la vida de la España rural con criterio 'noventayochista'.

Recordemos que Clarín acusó a Trigo de ser un "corruptor de menores" por la temática explícitamente sexual y erótica de algunas de sus obras, asunto que también ha sido estudiado por Granjel en el referido ensayo de 1975 glosando obras como "Las ingenuas", "Las evas 
del Paraíso" o "La sed de amar", concluyendo que Trigo en sus novelas denuncia el erróneo descubrimiento del amor que conduce " $a$ la mujer a la frigidez y el desequilibrio nervioso como última consecuencia y al hombre a una elemental y brutal manera de entender su encuentro con la mujer". Felipe Trigo, según Granjel, convierte el problema sexual en toda su obra escrita en una cuestión central de la existencia humana, para demostrarlo toma como ejemplo la relación amorosa de dos miembros de la burguesía, Jorge y Lola, en la novela "La sed de amar", en la cual aboga por la importancia de la educación sexual y cómo la carencia de la misma "conduce a una sociedad pervertida en la que los hombres quedan presos de la lujuria y las mujeres, tras el desencanto, son víctimas sin defensas para el desequilibrio nervioso e incluso la enfermedad orgánica”. Granjel aplicando su óptica de médico y psiquiatra, y de buen conocedor de la obra de Freud y de Jung, valora como documentos clínicos las descripciones de iniciación sexual que Trigo narra en sus novelas. En 2002, Teresa Gómez Trueba en "Imágenes de la mujer en la España de finales del XIX” insistió sobre el particular reivindicando la figura del escritor extremeño:

"Quizás entre todos aquellos escritores españoles que abordaron en sus obras el tema de la emancipación femenina, ninguno adoptó una postura tan original y progresista como el novelista Felipe Trigo, quien desde diferentes escritos abogó una y otra vez por una liberalización social de la mujer (...). Como bien ha señalado Lily Litvak, el mayor interés del 'feminismo' de Trigo reside en el hecho de que busca la emancipación de la mujer, sin tener como meta la imitación del hombre, sino el encuentro de la personalidad femenina, lo cual resulta más sorprendente en una época en la que las mismas feministas, sin lograr desprenderse de un claro sentido de inferioridad, confundian el éxito humano con el masculino".

Luis Sánchez Granjel insiste en su estudio en que la obra literaria de Trigo es social y reformadora, considerándolo ideológicamente dentro del socialismo utópico; autores como Muela Herraiz han profundizado en este aspecto en su obra periodística distinguiendo una etapa marxista y otra reformista, resaltando también en su obra novelística la influencia de Zola y su visión de la novela como Ciencia, aspecto que ya había subrayado Granjel al señalar la conocida declaración del escritor extremeño, que consideraba que había llegado a la novela como biólogo: "La Anatomía y la Fisiología y la Patología que sólo pueden estudiar la vida en la muerte o en la paralización y segmentación, son menos ciencias de la vida que la novela moderna, que la ha recogido y la observa y la experimenta a la vez en libertad absoluta...”. Párrafo que recuerda en cierta forma a la admiración de Zola por Claude Bernard y su reivindicación de una novela "experimental", merece la pena reproducir uno de los párrafos de "Le roman expérimental" del escritor francés:

"Dans mes études littéraires, jái souvent parlé de la méthode expérimentale appliquée au roman et au drame (...).

Je n'aurai à faire ici qu'un travail d'adaptation, car le méthode expérimentale a été établie avec une forcé et une clarté merveilleuses par Claude Bernard, dans son 'Introduccion á l'etude de la médecine experimentale'. Ce livre, d'un savant dont l'autorité est décisive, va me servir de base solide (...). Le plus souvent, il me suffira de remplacer le mot 'medecin' par le mot 'romancier', pour rendre ma pensé claire et lui apporter la rigueur d'une verité scientifique". 
FELIPE TRIGO

\section{EL MEDICO RURAL}

\author{
Prólogo de José Bergamín
}

\section{EDICIONES TURNER}

Figura 4: Portada de "El médico rural" de Felipe Trigo.

No podemos olvidar aquí evidentemente una de las novelas más consideradas por la crítica de Felipe Trigo, "El médico rural" (1912), comentada por Granjel en su artículo "Literatura y Medicina en la época del Noventa y Ocho" (1998). Felipe Trigo, como Pío Baroja -recuérdese que ambos abandonaron el ejercicio de la medicina-, ejercieron como médicos rurales; precisamente el escritor extremeño reflejó en su novela su experiencia médica en las poblaciones de Trujillanos y Valverde de Mérida, convirtiendo al protagonista de la misma Esteban Sicilia en el alter ego o contrafigura literaria del propio escritor; la novela está plenamente imbuida en la crítica social y posee cierto afán transformador, según apunta Granjel, que la sitúa dentro de los esquemas de la tradición naturalista: “...la novela (...) incorpora pormenorizadas descripciones del cotidiano quehacer profesional, reflexiones de indole social y una imprecisa aspiración a imponer mudanza en unas formas de vida ancladas en la estructura caciquil, degradación del viejo feudalismo...”.

La novela refleja, como es sabido, escenas de la vida médica rural, a través de las inseguridades de un joven médico al que los habitantes del pueblo deseaban ver en funciones tratando indigestiones, luxaciones, casos de paludismo, problemas cardíacos, inflamaciones oculares, otitis, hemorroides, escarlatina, difteria, tétanos, hidrocele, epitelioma labial, escrófulas, ciática, gripe, pleuritis, ántrax, delirium tremens, o extirpando una falange necrosada o atendiendo partos complicados, o aplicando inyecciones hipodérmicas de éter $y$ recetando cloral, antipirina, morfina, bromuro de sodio, quinina, láudano de Sydenham, ipecacuana en polvo, sueros antitetánico y antidiftérico, e incluso introduciendo cánulas laríngeas con el temor de tener que practicar una traqueotomía; todo un tratado, pues, de las ideas médicas y terapeúticas, así como de la medicina popular, de los albores del siglo XX.

Finalmente, como es sabido, Felipe Trigo en un aciago día de 1916, con el telón de fondo de la Primera Guerra Mundial, se quitó la vida, pero este es un capítulo que no podemos abordar aquí, pero que cuenta con estudios como el de Víctor Guerrero Cabanillas en su libro "Felipe Trigo, desorden mental y creatividad literaria”.

\subsection{PÍO BAROJA: JOSÉ DE LETAMENDI EN "EL ÁRBOL DE LA CIENCIA”}

Luis Sánchez Granjel ha dedicado a la vida y obra de Pío Baroja varios estudios; entre sus trabajos cabe destacar "Retrato de Pío Baroja" (1953) (figura 5), "Baroja y otras figuras del 98” (1960), "La personalidad médica de Pío Baroja” (1973) y "El último Baroja” (1992), sin 
olvidarnos de que en 1962 participó también en el gran empeño editorial dirigido por Fernando Baeza que lleva por título "Baroja y su mundo". Los estudios literarios de Granjel en líneas generales suelen estar muy valorados por los especialistas, pero quizás una de las críticas más entusiasta a su obra ha sido la que recientemente ha realizado José-Carlos Mainer en su biografía "Pío Baroja", autor que recuerda también la tesis doctoral dirigida por el historiador de Segura a Isabel Criado titulada "Personalidad de Pío Baroja. Trasfondo psicológico de un mundo literario" (1974). Leamos un fragmento de los merecidos elogios que le tributa Mainer:

"Lo biográfico y el análisis psicológico se mezclaron en el libro del historiador de la Medicina Luis Sánchez Granjel, 'Retrato de Pío Baroja' (1953) (...). Publicado todavía en vida del autor y en circunstancias políticas muy poco bonancibles, aquel 'Retrato' sigue siendo -por su probidad documental, su empatía con el autor estudiado y el buen tino de lector-uno de los mejores libros sobre nuestro escritor. En la dedicatoria a Pedro Laín Entralgo, Granjel reconoció su magisterio y las deudas interpretativas que tenía con el cercano volumen 'La generación del 98', pero el autor fue mucho más lejos que su maestro en este tupido trabajo...”.

Asimismo, Mainer, considera "El último Baroja" como un libro emocionado y leal que sigue siendo imprescindible para entender los años del ocaso del escritor vasco. Es muy difícil recibir elogios tan notables sobre todo cuando existen tantos y tantos estudios sobre la vida y obra del escritor donostiarra. Granjel ha estudiado a Baroja, con la paciencia que le caracteriza, desde los años mozos del escritor hasta sus últimos días, manteniendo incluso alguna relación personal y por carta con él, a alguna de ellas haremos alusión en estas pá- ginas. Vista la imposibilidad de analizar en este artículo todos y cada unos de los asuntos médicos estudiados por Granjel sobre la obra de Baroja, centraremos nuestros comentarios en un aspecto concreto: la fobia personal del escritor donostiarra a la figura de José de Letamendi, que como veremos mantuvo durante toda su vida, para ello nos serviremos de una novela fundamental "El árbol de la ciencia" y en el citado epistolario de Granjel con el escritor vasco.

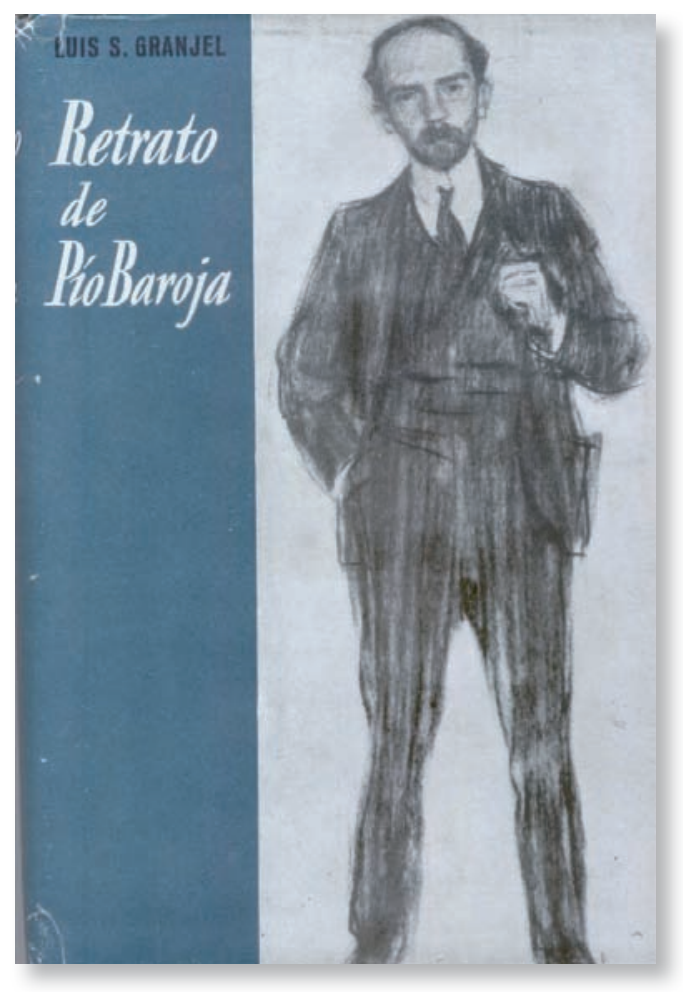

Figura 5: Portada de "Retrato de Pío Baroja" de Luis S. Granjel.

José de Letamendi i de Manjarrés (18281897) fue catedrático de Anatomía en Barcelona y de Patología en Madrid, precisamente fue Decano en la Facultad de San Carlos realizando una labor justamente valorada por José Luis Peset que lo considera en esta faceta 
como una figura clave para entender la enseñanza médica de la Restauración. En cambio, Granjel ha estudiado como el joven Pío Baroja tuvo una consideración muy desfavorable hacia este profesor que le propinó la calificación de suspenso en la asignatura que impartía en dos convocatorias seguidas, de todo esto queda testimonio escrito, por ejemplo, en la excelente novela "El árbol de la ciencia", en la cual el personaje de la misma, Andrés Hurtado, es un alter ego literario del propio escritor. Baroja describe al profesor Letamendi como un señor flaco, bajito, escuálido, con melenas grises y barba blanca, con cierto tipo de aguilucho, la nariz corva, los ojos hundidos y brillantes, que vestía una levita entallada y sombrero de copa. No tarda mucho el escritor vasco en derramar su bilis sobre Letamendi:

"Letamendi era de estos hombres universales que se tenían en la España de hace unos años, hombres universales a quienes no se les conocía ni de nombre pasados los Pirineos. Un desconocimiento tal en Europa de genios trascendentales se explicaba por esa hipótesis absurda, que, aunque no la defendía nadie claramente, era aceptada por todos, la hipótesis del odio y la mala fe internacionales que hacía que las cosas grandes de España fuera pequeñas en el extranjero y viceversa".

Debemos apuntar que Letamendi, según sus escritos, quiere restablecer la figura de Hipócrates, por eso algunos autores lo sitúan en la estela del neohipocratismo, con todos los matices que se quiera apuntar; pero al margen de esto en la citada novela barojiana aparece una crítica palmaria a la conocida fórmula de la vida de Letamendi y a sus argumentaciones filosóficas. La vida para Letamendi es, según se recoge en la novela, una función indeterminada entre la energía individual y el cosmos, que no pudiendo ser suma, ni resta, ni división, tiene que ser multiplicación. Las páginas que se dedican en la novela a esta cuestión y sobre todo la discusión entre los estudiantes de estas ideas filosóficas letamendianas son magistrales; el joven personaje, Andrés Hurtado, finalmente considera palabrería los argumentos de su profesor, pero no debe olvidarse que esta decepción le lleva a buscar libros de filósofos como Kant, Fitche o Schopenhauer. De hecho "El árbol de la ciencia", como bien ha apuntado Sergio Beser, es entre otras cosas un relato filosófico en que se noveliza el pensamiento de Schopenhauer, a partir de las lecturas que Baroja hace de la obra de este filósofo.

Pero volvamos a las argumentaciones letamendianas sobre el hombre, la vida y el cosmos recurriendo a sus propias palabras:

¿No es el hombre un ser corpóreo? ¿No es su cuerpo uno e indiviso? ¿No es la vida el acto de este cuerpo? ¿No es este acto la resultante dinámica de su energía individual, sin la cual no viven y de las energías cósmicas, sin cuyo concurso muere? ¿No nos conduce, en buena mecánica racional, (siendo I energía del individuo, $C$ la del Cosmos y V la resultante Vida), a plantear la ecuación $V=f(I C)$ ?".

Todas estas ideas de sumas, restas, multiplicaciones y divisiones en torno a la Vida son cuestionadas en la novela, como hemos apuntado ya, por el propio Andrés Hurtado, figura central de la misma, que como reacción se sumerge en la lectura de los filósofos citados; la profunda decepción que le produce Letamendi queda reflejada en el siguiente párrafo:

“-¿Pero no te basta con la filosofía de Letamendi?

-Si eso no es filosofía ni nada -replicaba Andrés-. Letamendi es un hombre sin una idea profunda, no tiene en la cabeza más que palabras y frases. Ahora, como vosotros no las comprendéis, os parecen extraordinarias". 
Las ideas de Letamendi, las expuestas y otras que giran en torno a la defensa del hipocratismo, han tenido partidarios y detractores, pero quizás uno de sus críticos más feroces fue Pío Baroja que lo llegó a calificar de "catedrático de cartón y cemento armado", al cual sólo reconoce como mérito -según apunta Granjeltener alguna condición de literato y de orador efectista. Esta inquina personal hacia Letamendi la mantiene hasta el final de sus días, hecho que ha demostrado Granjel haciendo público su epistolario con el escritor vasco. Granjel en 1951 le envió al escritor donostiarra para su consideración su ensayo "La personalidad médica de Pío Baroja”. Curiosamente en su contestación, Baroja, escribe poco más de una línea para darle las gracias a Granjel, dedicando casi la totalidad de la misiva a sus refutaciones de la obra de Letamendi. Leamos un fragmento de la misma recordando que esto se escribe a principio de los años cincuenta:

"Yo sigo no creyendo en la genialidad de Letamendi ni en el valor de sus teorías. No tengo gran afición a la medicina y sin embargo leí hace cuarenta años en un hotel de París la 'Introducción al estudio de la Medicina experimental' y me produjo un gran entusiasmo.

La ecuación de Letamendi: La vida igual a la multiplicación de la energía individual por el cosmos, me parece en parte una vulgaridad y en parte falsa.

Un hombre sin energía, un príncipe de otro tiempo como Carlos II el Hechizado en un medio ambiente rico sería siempre un pobre miserable, no podría tomar del medio ambiente más que muy poco.

Lo mismo le pasaría con factores cambiados al tipo enérgico y atrevido en un ambiente pobre, metido en una cárcel o en una isla desierta sin posibilidad de escapar. Para mí lo que dice Letamendi no tiene ningún valor. Todo me pa- rece en él fuegos artificiales. De ahí que en los medios científicos nadie le haya tomado en serio".

Como se puede apreciar hay fobias que se llevan a cuestas durante toda una vida; en la citada carta, Baroja, sigue argumentando contra la teoría de Letamendi enfrentándola incluso con una de las obras médicas más vigorosas escritas en la segunda mitad del siglo XIX, nos referimos al célebre tratado de Claude Bernard "Introducción al estudio de la Medicina experimental". En las teorías de Letamendi se pueden cuestionar muchos aspectos; pero no se debe olvidar, como ha demostrado Peset, que no fue un hombre totalmente al margen de las novedades médicas del Positivismo, ya que como Decano abogó porque se dotara la madrileña Facultad de Medicina de San Carlos de laboratorios de histología y microbiología, demostrando con ello su interés por la medicina de laboratorio, y por la necesidad de contar con quirófanos en los que se hicieran las intervenciones quirúrgicas con la debida "asepsia" o que los niños enfermos contaran con salas espaciosas para ser asistidos durante su convalecencia en el hospital, etc.. Todo ello se puede leer en documentos redactados por Letamendi y en el Memorial que envió al Ministro de Fomento a finales de 1890, fecha por cierto no muy distante a la que impartió clases a Pío Baroja (recuérdese que éste comenzó la carrera en 1887). En estos escritos letamendianos se observan ideas de marcado perfil regeneracionista en torno a la enseñanza y el ejercicio clínico de la medicina en el Hospital de San Carlos, apreciándose que su figura es más compleja de lo que apuntó Pío Baroja en sus comentarios sobre sus teorías médico filosóficas.

Luis Sánchez Granjel en sus estudios sobre Baroja supo apreciar muy tempranamente 
que una novela como "El árbol de la ciencia", publicada en 1911, además de otras obras, era una fuente de conocimientos ineludible para conocer la personalidad médica del escritor vasco, sobre todo de los años en que estudia su carrera de medicina y su corto ejercicio profesional como médico en Cestona, plaza en la que cesó en septiembre de 1895. Nosotros en este escrito hemos explorado tan sólo el asunto letamendiano; pero la novela en cuestión, como apunta Sergio Beser, además de ofrecer un retrato de la formación médica de Baroja y de novelizar el pensamiento de Schopenhauer, tiene una inusitada vigencia como documento de la crisis intelectual que vive la cultura y sus hombres en la España de la transición del siglo XIX al XX, presentando un cuadro crítico y negativo de la sociedad española de la época.

\subsection{MÉDICOS Y ENFERMOS EN LA OBRA DE AZORÍN}

El profesor Sánchez Granjel ha desgranado con esmero en ensayos, como "La Generación literaria del 98", la nómina de autores que descubrieron rasgos de identidad entre sus integrantes, como por ejemplo Juan Maragall y Gabriel Maura, pero hace especial hincapié en los escritos de Azorín que están fechados entre 1905 y 1910, pero sobre todo señala al escritor levantino como el que en 1913 utilizó por primera vez el controvertido término de Generación de 1898, vinculándolo a la fecha del desastre colonial, considerando incluso como precursores de la misma a escritores de generaciones anteriores como Campoamor, Echegaray y Galdós, cuestiones sobre las que no vamos a insistir más en este artículo.

José Martínez Ruiz, Azorín, cultivó el ensayo, el teatro y la novela; sobre su quehacer en este último género literario se han dicho muchas cosas; por ejemplo, fue calificado por Julián Marías como un narrador que poseía una mirada intensa, una mirada que precisamente ya hizo destacar a Ortega, en 1917, su enorme talento para captar los "primores de lo vulgar"; precisamente esa capacidad azoriniana para plasmar personajes discretos y modestos o la emoción ante un paisaje, y su prosa limpia y clara, ha hecho decir a algunos autores que detrás de los personajes de Azorín siempre está Azorín, y esto lo ha sabido ver perfectamente Granjel cuando ha explorado las obras del escritor levantino, consiguiendo dibujar no sólo un panorama de su evolución humana y política sino sobre todo trazar un retrato psicológico a través de sus opiniones sobre la medicina, los médicos, pero sobre todo cuando escribe sobre la salud y la enfermedad. Recuérdese que Sánchez Granjel le dedicó un extenso ensayo titulado "Retrato de Azorín" (1958) (figura 6), pero en 1955 había publicado ya en "Archivos Iberoamericanos de Historia de la Medicina" un texto titulado "Médicos y enfermos en las obras de Azorín", volviendo sobre idéntico asunto en “Baroja y otras figuras del 98” (1960).

\section{LUIS S. GRANIEI}

\section{RETRATO DE AZORIN}

Figura 6: Detalle de la portada de "Retrato de Azorín" de Luis S. Granjel.

Desde nuestro punto de vista "Retrato de Azorín" es una de las empresas ensayísticas más complicadas de las llevada a cabo por Granjel porque dedica muchas páginas de la misma a captar el carácter, la psicología del maestro de Monóvar o de sus personajes literarios, tanto en los testimonios de quienes lo conocieron 
como en sus ensayos, pero sobre todo en su obra narrativa que ha sido calificada por Mario Vargas Llosa, en su discurso de ingreso en la Real Academia Española de la Lengua, como "Las discretas ficciones de Azorín"; espigar en la narrativa azoriniana creemos que es difícil, porque como apunta el escritor peruano "las personas, (...), no pasan de siluetas, sombras, entelequias", eso sí con una prosa cuidada "de precisión maniática y respirar simétrico", mostrándose más audaz cuando escribe artículos o pequeños ensayos. Vargas Llosa insiste, desde la admiración que le profesa, que Azorín sabía describir más que contar. Camilo José Cela, en su discurso de contestación, apunta que Azorín sufre viendo como se quema el tiempo y el autor de "La tía Julia y el escribidor" insiste en que es un "descriptor pertinaz de lo exterior (...), como si todo lo que no formara parte del mundo físico lo ahuyentara", de manera que refleja un "mundo sin tiempo y también sin sexo". Esta y otras cuestiones, desde la erudición y la exégesis, las supo ver Granjel incluida la honda preocupación por el tiempo que tenía Azorín:

"Muy temprana es, en la vida íntima de Azorin, su preocupación por el tema del tiempo, y tanto que su primera vivencia la experimentó, aún niño, durante su estancia como escolar en Yecla, según revelación que el escritor hace en 'Las confesiones de un pequeño filósofo'. Años después, alcanzando ya, con su vida, la frontera de la madurez, el tema que empieza a obsesionarle, reaparece en el 'Diario de un enfermo' $y$ en 'La voluntad', y como en estas obras en otros muchos escritos cuya simple mención abrumaría”.

En 1918 Azorín escribía sobre la labor destructora del tiempo, "deshaciendo las cosas"; Ortega decía que el escritor levantino no era un filósofo de la historia sino un "sensitivo" de la historia; esto mismo creemos que lo ha sabido ver Granjel cuando analiza la vida cotidiana de Azorín o cuando va desgranando con paciencia entomológica su ascetismo, su tristeza y el hermetismo de su mundo psíquico, así como su sentimiento de que el hombre es indiferente al dolor ajeno o el miedo a no poder seguir escribiendo. Vargas Llosa lo vio solamente una vez, en 1958, y tuvo la sensación de ver a un "viejecillo mudo, translúcido y aéreo"; en esta línea, Granjel reproduce algunos párrafos de Ortega y Gasset para reflejar su tendencia a la soledad: “...no consiste ya simplemente en que se halle sin nadie al lado, sino que se ha convertido en una realidad, en un cuerpo transparente y sólido, en un caparazón cristalino que llevase en torno de su persona. Cuando alguien le habla se sorprende e inquieta como si de súbito le hubieran quebrado la vidriera de soledad circundante,...". Granjel realiza un esfuerzo notable para explorar la personalidad íntima de Azorín a través de sus personajes, como es el caso de " $X$ " que en sus años ancianos siente que la salud con los años es como un "hilito quebradizo". En la década de los cuarenta Azorín creó un personaje, Antonio Quiroga, del que dice: “...del mundo externo sólo conservo las nociones más escuetas y elementales; desecho de mí, aparto de mí hago esfuerzos para rechazarlo todo cuanto pueda ser enlace con las cosas, con la vida tangible, con el mundo real'. Es preciso aclarar que el ensimismamiento de José Martínez Ruiz, o por mejor decirlo de los personajes en los que se refleja literariamente, no es cosa de los años postreros del escritor sino que en obras tempranas como "La voluntad" presenta a su personaje como un "mozo ensimismado $y$ taciturno, habla poco y en voz queda”. Otro personaje, Antonio Azorín, dice de sí mismo: "Yo me veo solo, yo me veo triste; yo veo que mi juventud va pasando estérilmente, sin una ternura, sin una caricia, sin un consuelo". 
La dificultad, pues, de estudiar biográfica y patográficamente a Azorín reside en que el escritor de Monóvar se muestra y se esconde a través de sus personajes, y se corre el riesgo en muchas ocasiones de atribuir a su persona sentimientos o enfermedades que pueden ser creaciones literarias, aunque no podemos olvidar que Pío Baroja que le conoció bien lo calificó de "hombre retraído y frío". Por todo ello Granjel haciendo uso de sus conocimientos psiquiátricos, con mucha prudencia escribe lo siguiente:

"La introyección abre la puerta en quien la vive, en ocasiones, a la desviación neurótica; sin pretender asegurar que Azorín lo sea o lo haya sido un día, sí es bien cierto que su personalidad, tal como ella se descubre, con singular frecuencia, en el cuerpo de su obra, ofrece rasgos que autorizan a sospechar su presencia".

No se puede olvidar que en su "Retrato de Azorín" Granjel insiste, por ejemplo, en que autores como Marco Merenciano han estudiado el perfil psicopatológico de algunos personajes creados por José Martínez Ruiz, Azorín, situando el asunto patográfico en su justo término. Asimismo en el referido ensayo ha explorado magistralmente también la vivencia de la vejez en la obra azoriniana, sobre todo esa creencia de que el anciano "es un enfermo", "sano hasta cierto punto", que debe estudiarse a sí mismo y cuidarse: “Sepamos callar, sepamos dormir, sepamos respirar, sepamos comer!". Consejos muy razonables que seguramente ayudarían a José Martínez Ruiz a convertirse en nonagenario.

A partir de los citados estudios de Granjel se ha apreciado también que la obra de Azorín muestra una extensa nómina de médicos, reales o ficticios, así como opiniones sobre la medicina y lo que es más importante sobre la vivencia de la enfermedad. Citaremos aquí solamente la aparición de Gregorio Marañón y de Teófilo Hernando, en novelas como "El enfermo" y "María Fontán", con los nombres figurados respectivamente de García de Rodas y Facundo Irala. En líneas generales la figura del médico en la obra de Azorín recibe un tratamiento literario de beneplácito y admiración, y es que como expresa Marañón y subraya Granjel el mundo íntimo de los entes de ficción azorinianos están llenos de bondad, "en la humanidad de Azorín no existe el demonio". Entre las cualidades que debe poseer el médico señala, por ejemplo la de "no ser asombradizo" y "no ser lenguaraz". Una vez más asoma el afán de discreción en la obra azoriniana.

Para finalizar si tuviéramos que quedarnos con un personaje de la obra literaria de Azorín para explorar la vivencia personal de la enfermedad o de las enfermedades sería, sin duda, el de Víctor Albert de la novela "El enfermo", en la que el citado personaje realiza reflexiones sobre las fronteras de la misma: “...fronteras, porque se trata de un terreno, que no siendo ya el de la salud, no es todavía el de la enfermedad". Víctor Albert es muy consciente de que en la enfermedad "somos otros de los que antes éramos. Hemos perdido una personalidad $y$ hemos ganado otra. Y esta otra vale acaso, y sin acaso, más que la precedente". Azorín, pues, antes que Laín Entralgo y Susan Sontag, expone con sencillez la idea de que la enfermedad constituye un episodio biográfico que puede cambiar la vida de la persona. Granjel ha glosado también la neurosis que padece este personaje, el temor obsesivo a varias enfermedades: "A mi pesar, contra mi voluntad, en estos momentos ya no soy yo; soy de Friedriech, o de Little, o de Stokes-Adams; lo soy de un modo pasajero. $Y$ en forma ineluctable, como un siervo adscrito a la gleba de Bright, el terrible Bright". 
Granjel plasma aquí algo que le ha preocupado siempre, estudiar la vivencia de enfermedad a través de los personajes que ofrece la literatura, consiguiéndolo plenamente con este Víctor Albert de Azorín y también con el don Pablo Silva de la novela "Doña Inés". Granjel resume certeramente también el padecimiento de Víctor Albert en su ensayo "Literatura y medicina" (2001), como testimonio valioso para alcanzar un conocimiento más humanizado de la enfermedad:

"Testimonio que considero valioso de la 'vivencia de enfermedad' lo ofrece la novela, rigurosamente autobiográfica, de Azorín, 'El enfermo', publicada en 1943, al regreso de su voluntario exilio en París; el protagonista del relato, Víctor Albert, es contrafigura del autor, vive edad de su vida que corresponde a la de Azorín y por temperamento hace recordar a los enfermos hipocondríacos (...). Víctor Albert tiene personalidad 'cambiadiza e impresionable', lo que favorece su conversión en 'enfermo imaginario'; su existencia es dominada por supuestas dolencias que alimenta con lecturas de obras de medicina y la amistad de los médicos que atienden las claudicaciones de su organismo (...).

Posee también valor informativo la afirmación que sustenta Víctor Albert sobre los cambios que la enfermedad, real o creída, impone en el comportamiento...”.

La prosa de Azorín brilló especialmente también en los periódicos realizando crónicas de los balnearios vascos de Alzola, Zaldívar, Carranza y Cestona, estudiadas por Urkía en su ensayo "Literatura balnearia en España: Azorín y Baroja". Un tema este de los balnearios del cual también se ha ocupado Granjel en su monografía "Viaje al Balneario" publicada en 1997, que no glosamos en este artículo porque merece consideración aparte.

\section{EPÍlOGO}

Luis Sánchez Granjel, como es sabido, ha desarrollado durante décadas una ingente labor historiográfica abarcando desde la medicina española de la Antigüedad y Edad Media hasta la Edad Contemporánea; en este sentido cabe recordar el consejo crucial que le dio Laín Entralgo: “Por qué no dedica usted a la historia de la medicina española su atención principal?” $\mathrm{Y}$ a este menester consagró Granjel su trabajo durante décadas desde la cátedra de Historia de la Medicina de Salamanca, fundando primero un Seminario de Historia de la Medicina Española, en 1955, que fue transformado en Instituto en 1969 en el antiguo edificio del Colegio Mayor del Arzobispo Fonseca. En el seno del mismo cultivó, pues, la investigación de archivo, y creó una importante escuela histórico médica que ha traspasado ampliamente las fronteras salmantinas; pero como hemos apuntado desarrolló también en el seno de este Instituto su vocación literaria, que le acompaña desde su juventud, de manera que en su persona confluyen de forma rigurosa la doble condición de historiador de la medicina y de historiador de la literatura; precisamente a esta última línea de trabajo hemos consagrado este artículo, abarcando parcialmente sus estudios sobre la denominada Generación del 98, enfocándolo específicamente en el punto donde convergen las cuestiones médicas con la literatura o la crítica literaria y más concretamente a través de figuras como Santiago Ramón y Cajal, Felipe Trigo, Pío Baroja y Azorín, recordando tan solo en nuestro relato -por haber sido motivo de un estudio anterior- la importante psicobiografía que dedicó a Miguel de Unamuno. Asimismo hemos intentado precisar en estas páginas que la condición de estudioso de Granjel en torno a la citada Generación no queda en la mera enumeración epi- 
sódica de hechos, acontecimientos y figuras, sino que muy al contrario se muestra como un crítico literario riguroso que cuestiona en sus trabajos la denominación con la que tradicionalmente se encuadra a los escritores de la citada Generación, prefiriendo la denominación de 'Promoción literaria de la Regencia'. Somos conscientes de que la obra granjeliana merece otros estudios en esta línea específica de la literatura y la medicina, a esta tarea intentaremos consagrar nuestros esfuerzos en el futuro.

\section{BIBLIOGRAFÍA}

- Abellán, J.L. (1993) Historia crítica del pensamiento español. La crisis contemporánea I. La Restauración canovista 1875-1897. Tomo 6. Círculo de Lectores, Barcelona. - Álvarez-Junco, J. (2012) Mater Dolorosa. La idea de España en el siglo XIX. Taurus historia, Madrid.

- Azorín (1961) El enfermo. Biblioteca Nueva, Madrid.

- Azorín (2013) La ruta de don Quijote. Alianza editorial, Madrid.

- Baeza, F. (dir.) (1962) Baroja y su mundo. Ediciones Arion, Madrid.

- Baroja, P. (2006) El árbol de la ciencia. Caro Raggio/Cátedra, Madrid.

- Bergasa, V. (1997) Felipe Trigo un modernista europeo. El Mercure de France. Anales de Filología Francesa 8: 51-65.

- Bergamín, J. (1974) Prólogo. En Trigo, F.: El médico rural. Ediciones Turner, Madrid.

- Beser, S. (1983) El árbol de la ciencia. Pío Baroja. Editorial Laia, Barcelona.

- Blanco-Aguinaga, C. (1970) Juventud del 98. Siglo XXI, Madrid.

- Cacho-Viu, V. (1997) Repensar el 98. Biblioteca Nueva, Madrid.

- Carreras-Panchón, A. (2003) Entrevista a Luis Sánchez Granjel. Eidon. Revista de la Fundación de Ciencias de la Salud 12: 28-33.

- Ciaella, L. (2006) Making emotion visible: Felipe Trigo and 'La sed de amar' (educación social). Decimonónica
1: 28-43.

- Cruz-Hernández, M. (1998) El 98 desde dentro. Anuario Filosófico 31: 25-53.

- Cuvardic-García, D. (2009) El debate modernismo-Generación del 98. Revista Reflexiones 88,2: 101-112.

- Díaz-Plaja, G. (1979) Modernismo frente a Noventa y Ocho: una introducción a la literatura española del siglo XX. Espasa-Calpe, Madrid.

- Fox, E.I. (1989) El concepto de Generación de 1898 y la historiografía literaria. Disponible en http://cvc.cervantes.es/literatura/aih/pdf/10/aih_10_2_089 (Consultado el 8 de diciembre de 2013).

- Gómez-Trueba, T. (2002) Imágenes de la mujer en la España de finales del XIX: <santa, bruja o infeliz ser abandonado>". Disponible en http://www.lehman.cuny.edu/ ciberletras/v06/gomeztrueba.html (Consultado el 8 de diciembre de 2013).

- Granjel, Luis S. (1949) El tema de la enfermedad en 'La Montaña mágica’ de Thomas Mann. Medicina Clínica XIII: 56-59.

- Granjel, Luis S. (1951) La personalidad médica de Pío Baroja. Archivos Iberoamericanos de Historia de la Medicina III: 169-204.

- Granjel, Luis S. (1953) Retrato de Pío Baroja. Editorial Barna, SA, Barcelona.

- Granjel, Luis S. (1955) Médicos y enfermos en las obras de Azorín. Archivo Iberoamericano de Historia de la Medicina y de Antropología médica VII: 547-559.

- Granjel, Luis S. (1957) Retrato de Unamuno. Ediciones Guadarrama, S.L, Madrid.

- Granjel, Luis S. (1958) Retrato de Azorín. Ediciones Guadarrama, SL, Madrid.

- Granjel, Luis S. (1959) Panorama de la Generación del 98. Ediciones Guadarrama, SL. Madrid.

- Granjel, Luis S. (1960) Baroja y otras figuras del 98. Ediciones Guadarrama SL, Madrid.

- Granjel, Luis S. (1962) Biografía de 'Revista Nueva' (1899). Ediciones de la Universidad de Salamanca, Salamanca.

- Granjel, Luis S. (1966) La Generación literaria del Noventa y Ocho. Ediciones Anaya, Salamanca.

- Granjel, Luis S. (1966) Edición de Juan Bautista Amorós 
(Silverio Lanza): Obra selecta. Selección y estudio preliminar. Ediciones Alfaguara. Madrid, pp. 9-130.

- Granjel, Luis S. (1973) Médicos novelistas y novelistas médicos (Discurso de ingreso en la Real Academia de Medicina de Salamanca, Salamanca.

- Granjel, Luis S. (1974) Felipe Trigo. Medicina y literatura. Cuadernos de Historia de la Medicina Española XIII: 371-394.

- Granjel, Luis S. (1975) Felipe Trigo. Medicina y Literatura. En II Reunión Nacional de Médicos Escritores. Mérida, pp. 171-187.

- Granjel, Luis S. (1981) Maestros y amigos de la Generación del Noventa y Ocho. Ediciones Universidad de Salamanca, Salamanca.

- Granjel, Luis S. (1988) Memoria personal. Seminario de Historia de la Medicina Vasca, Bilbao.

- Granjel, Luis S. (1990) Viaje al Balneario. Ediciones Sociedad Vasca de Historia de la Medicina, San Sebastián.

- Granjel, Luis S. (1992) El último Baroja. Sociedad Vasca de Historia de la Medicina, Salamanca.

- Granjel, Luis S. (1998) Una vida de historiador. Real Sociedad Bascongada de los Amigos de País, Donostia-San Sebastián.

- Granjel, Luis S. (1998) Literatura y medicina en la época del Noventa y Ocho. El Médico. Profesión y Humanidades 683: 20-24.

- Granjel, Luis S. (1999) Psicobiografía de Unamuno (Un ensayo de interpretación). Real Sociedad Bascongada de los Amigos del País, San Sebastián.

- Granjel, Luis S. (2001) Literatura y medicina (cuaderno de trabajo). Sociedad Vasca de Historia de la Medicina, San Sebastián.

- Granjel, Luis S. (2005) Lectura médica del Quijote. Anales de la Real Academia Nacional de Medicina 1: 131143.

- Granjel, Luis S. (2011) Literatura y medicina. En Gracia, D.: Medicina y Humanidades. Real Academia Nacional de Medicina. Madrid, pp.103-110.

- Granjel, Luis S. (2013) La Academia Nacional de Medicina en la Segunda República (La Academia en San Sebastián). Fundación del Colegio de Médicos de Guipúzcoa, San Sebastián.
- Guerrero-Cabanillas, V. (2007) Felipe Trigo Cabanillas, desorden mental y creatividad literaria. Consejería de Cultura y Turismo. Ayuntamiento de Villanueva de la Serena.

- Hernández-Lobato, J. (2009) Hipotexto bíblico y Haggadah judía en El árbol de la ciencia: El Génesis según Baroja. Revista de Literatura 141: 85-110.

- Heredia-Soriano, A. (1998) Concepto del 98. Anuario Filosófico 31: 9-24.

- Heredia-Soriano, A (sfe) Realidad histórica y Generación del 98. Disponible en http://www.canela.org.es/ cuadernoscanela/canelapdf/cc10heredia.pdf (Consultado el 8 de diciembre de 2013).

- Herrera-Rodríguez, F. (1998) Enfermedad y guerra colonial en Cuba y Puerto Rico. El Médico. Profesión y Humanidades 683: 82-88.

- Herrera-Rodríguez, F. (2011) Un repaso de Granjel a las 'neurosis' de Unamuno. En: Las enfermedades de Sísifo. Reflexiones sobre literatura, medicina y enfermedad. Cádiz, pp. 79-96.

- Herrera-Rodríguez, F. (2013) Epístola 'literaria’ al profesor Sánchez Granjel. Intervención en el homenaje al profesor Granjel celebrado en el Colegio de Médicos de Salamanca el día 7 de septiembre de 2013. Inédita.

- Laín, P. (1975) La Generación del Noventa y Ocho. Espasa-Calpe, Madrid.

- Laín, P. (1987) La enfermedad humana. En Albarracín, A. (dir.): Historia de la enfermedad. Saned, Madrid, pp. XI-XVII.

- Laín, P. y Seco, C. (eds.) (2005) España en 1898. Las claves del desastre. Galaxia Gutemberg y Círculo de Lectores, Barcelona.

- Mainer, J.C. (2011) La Edad Contemporánea. En Breve historia de la literatura española. Alianza editorial, Cádiz, pp. 431-674.

- Mainer, J.C. (2012) Pío Baroja. Taurus, Madrid.

- Marías, J. (1975) Literatura y generaciones. Espasa-Calpe, SA. Madrid.

- Martínez San Martín, A. (1983) La narrativa de Felipe Trigo. Editorial CSIC, Madrid.

- Mellizo, F. (1971) Los cazadores de recuerdos. Reportaje de los grandes momentos de la Medicina (El Instituto de 
Historia de la Medicina de Salamanca). Tribuna Médica: VIII: 13.

- Muelas-Herraiz, M. (1986) La obra narrativa de Felipe Trigo. Tesis doctoral. Universidad de Alicante. Disponible en http://www.biblioteca.org.ar/libros/140116. pdf (Consultado el 8 de diciembre de 2013).

- Peiro-Rando, E. (1966) La obra científica del Dr. Letamendi. Disponible en http://www.raco.cat/index.php/ AnalesMedicina/article/viewFile/142945/254217 (Consultado el 8 de diciembre de 2013).

- Peset, J.L. (1998) José de Letamendi, Decano de la Facultad de San Carlos. Cuaderno del Instituto Antonio de Nebrija 1: 211-223.

- Ramón y Cajal, S, (1978) Charlas de café. Espasa Calpe, SA, Madrid.

- Ramón y Cajal, S. (1991) Reglas y consejos sobre investigación científica. Los tónicos de la voluntad. Espasa Calpe, Madrid.

- Ramón y Cajal, S. (2009) La mujer. Psicología del Quijote y el Quijotismo. Formación Alcalá, Alcalá la Real.

- Ramsden, H. (1974) The 1898 Movement in Spain. University Press, Manchester.

- Riera-Palmero, J. (2003) Medio siglo de historiografía médica española: aproximación a la obra de Luis S. Granjel. Llull 26: 257-278.

- Sarró, R. (1963) El sistema mecánico-antropológico de José de Letamendi. Discurso de recepción de Académico. Real Academia de Medicina de Barcelona, Barcelona.

- Sontag, S. (1980) La enfermedad y sus metáforas. Muchnik Editores, Barcelona.

- Tejerizo, L.C. (2003) Luis Sánchez Granjel. El hombre que hay detrás del historiador. Trafotex Fotocomposición, S.L, Salamanca.

- Trigo, F. (1974) El médico rural. Ediciones Turner, Madrid.

- Urkía-Etxabe, J.M. (1998) El mundo de los balnearios. La crisis de 1898. El Médico. Profesión y Humanidades 683: 52-55.

- Urkía-Etxabe, J.M. (2006) Literatura balnearia en España: Azorín y Baroja. Balnea 1: 41-62.

- Vargas-Llosa, M (1996) Las discretas ficciones de Azorín. Discurso de ingreso en la real Academia Española de la Lengua. Discurso de contestación Camilo José Cela. Barcelona.

- Zola, E. (1881) Le roman expérimental. G. Charpentier editeur, Paris. 